\title{
David Charles, La Fortune des Rougon, roman de la Commune
}

\section{Chiara Lanciano}

\section{(2) OpenEdition}

10 Journals

\section{Édition électronique}

URL : http://journals.openedition.org/studifrancesi/9323

DOI : 10.4000/studifrancesi.9323

ISSN : 2421-5856

Éditeur

Rosenberg \& Sellier

\section{Édition imprimée}

Date de publication : 1 juin 2008

Pagination : 220

ISSN : 0039-2944

\section{Référence électronique}

Chiara Lanciano, «David Charles, La Fortune des Rougon, roman de la Commune », Studi Francesi [En ligne], 154 (LII | I) | 2008, mis en ligne le 30 novembre 2015, consulté le 08 janvier 2021. URL : http:// journals.openedition.org/studifrancesi/9323; DOI : https://doi.org/10.4000/studifrancesi.9323

Ce document a été généré automatiquement le 8 janvier 2021.

\section{(c) (i) (9)}

Studi Francesi è distribuita con Licenza Creative Commons Attribuzione - Non commerciale - Non opere derivate 4.0 Internazionale. 


\title{
David Charles, La Fortune des Rougon, roman de la Commune
}

\author{
Chiara Lanciano
}

\section{RÉFÉRENCE}

DAVID CHARLES, La Fortune des Rougon, roman de la Commune, «Romantisme: La Turquie», n. 131, mars 2006, pp. 99-114.

1 À travers l'analyse de la chronologie des publications successives de «La Fortune des Rougon», d'abord sous forme de feuilletons puis en volumes chez Lacroix et chez Charpentier, David Charles démontre comment la diffusion du roman de Zola est directement liée à la topographie des événements de la Commune. Le roman nous plonge dans la réalité d'une famille de la bourgeoisie de Plassans en proie à une insurrection locale et apparaît comme métaphore de la répression: la préface du premier volume s'adresse aux lecteurs de 1871-1872, qui ont déjà vécu la Semaine sanglante. L'auteur s'intéresse de près aux modifications apportées au texte du feuilleton paru à partir de 1969 à la lumière des évènements de la commune et authentifie le cycle de romans de Zola comme «le sceau de la répression de la Commune sur l'histoire de la République». 